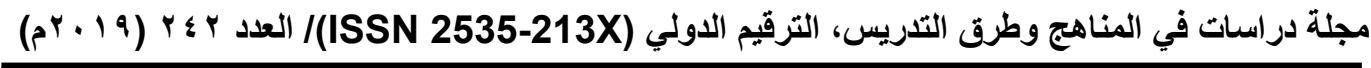

\title{
Flipped Demonstration Program for Kindergarten Prospective Teachers' English Pronunciation Learning and Teaching
}

By

\section{Dr. Mohammad Abu El-Magd* Dr. Neveen Ahmad Khalil** \\ 2019}

\begin{abstract}
This research aimed to develop KG prospective teacher's English pronunciation skills as well as improve their English pronunciation teaching performance to $\mathrm{KG}$ kids. The research design was one group pre and post-test quasi-experimental design. The participants were 72 2nd year KG prospective teachers at Ismailia Faculty of Education in Suez Canal University. In fulfillment of their future career's basic needs as language teachers for young learners, this research was oriented towards the participants' English pronunciation learning and teaching. A proposed program was developed and implemented via the use of Flipped Demonstration as an integrated pedagogical approach. There are two modules for the proposed program. Module one is Pronunciation Learning (the basic pronunciation skills needed by the $\mathrm{KG}$ prospective teachers) and module two is Pronunciation Teaching (the practical adapted techniques for teaching pronunciation to KG kids). Three tools were developed, validated and implemented by the researchers. They were: 1) English Pronunciation Skills Test, 2) Performance Observation Sheet for KG English Pronunciation Teaching and 3) Open Interviews with the participants by the end of experimentation. The findings revealed that the proposed program had a significant positive effect on the $2^{\text {nd }}$ year $\mathrm{KG}$ prospective teachers' Pronunciation Learning and Teaching.
\end{abstract}

Key Words: Flipped Classroom, Flipped Learning, Pronunciation Skills, Teaching Pronunciation, Demonstration and KG Prospective Teachers

* Associate Professor of TEFL, Ismailia Faculty of Education, Suez Canal University, Egypt.

** Associate Professor of KG Curricula, Ismailia Faculty of Education, Suez Canal University, Egypt. 


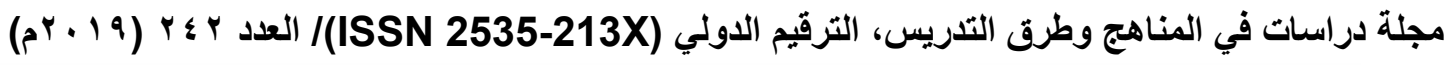

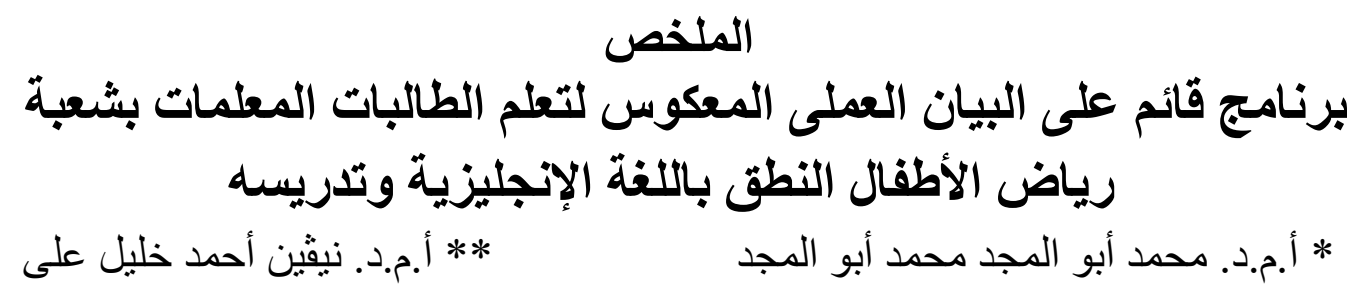

هدفت الدراسة إلى تتمية مهار ات النطق باللغة الإنجليزية لدى الطالبات المعلمات بشعبة رياض الأطفال وتحسين الأداء التدريسى للنطق باللغة الإنجليزية لدى أطفال الروضة. وكان التصميم التجريبي للاراسة هو الإسيا

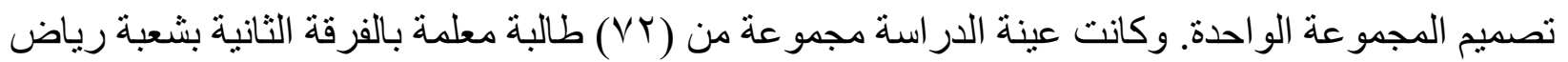
الأطفال بكلية التربية بالإسماعيلية (جامعة قناة السويس). ونظرًا للاحتياجات المهنية المستقلية للطالبات المعلمات بشعبة رياض الأطفال كمعلمات اللغة الإنجليزية للأطفال الصغار، توجهت الدراسة الحالية نحو تعلمهن النطق باللغة الإنجليزية وكيفية تدريسهن لأطفال الروضة. وكانت أداة المعالجة التجرييية لتحقيق هذا الهدف هي برنامج قائم على البيان العملى المعكوس لتعلم الطالبات المعلمات بشعبة رياض الأطفال النطق باللغة الإنجليزية وكيفية تدريسهن. و هناك موديو لان لهذا البرنامج: الموديول الأول عن تعلم النطق (مهار ات النطق الأساسية التى تحتاج إليهن الطالبات المعلمات بشعبة رياض الأطفال) و الموديول الثانى عن تدريس النطق (الأساليب العملية المناسبة لتدريس النطق لأطفال الروضة). وقد نم تطوير البرنامج وتطبيقه باستخدام البيان العملى المعكوس و الذى يعد مدخل تدريسى متكامل بين البيان العملى و الفصل المعكوس. وكانت أدوات القياس للتحقق من الفروض وفاعلية البرنامج هي: اختبار مهارات النطق، وبطاقة ملاحظة الأداء التدريسى للنطق، و هما من إعداد الباحثان وقد نم التحقق من صدقهما وثباتهما، بالإضافة إلى مقابلات مفتوحة تمت بنهاية المعالجة التجريبية للبرنامج للتحقق من مستوى رضا ومدى أستفادة الطالبات المعلمات بشعبة رياض الأطفال كمعلمات اللغة الإنجليزية للأطفال الصغار من البرنامج المقترح و القائم على البيان العملى المعكوس. و أسفرت نتائج الدر اسة عن أن البرنامج القائم على البيان العملى المعكوس له تأثثير إيجابى كبير ودال على تعلم الطالبات المعلمات بالفرقة الثانية بشعبة رياض الأطفال النطق باللغة الإنجليزية وتدريسه. الكلمات المفتاحية: الفصل المعكوس، التعلم المعكوس، البيان العملى، النطق باللغة الإنجليزية، تدريس النطق، الطالبات المعلمات بشعبة رياض الأطفال. * أستاذ مناهج وطرق تدريس اللغة الانجليزية المساعد بكلية التربية بالإسماعيلية جامعة قناة السويس

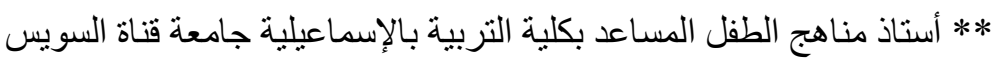




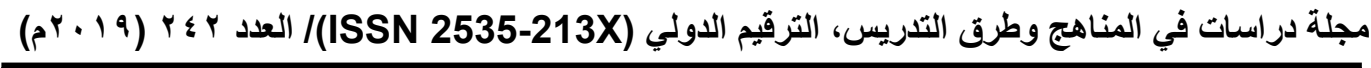

Flipped Demonstration Program for Kindergarten Prospective

Teachers' English Pronunciation Learning and Teaching

By

\section{Dr. Mohammad Abu El-Magd* Dr. Neveen Ahmad Khalil**}

\section{Introduction}

Good English Pronunciation leads to an efficient language learning whereas bad pronunciation causes difficulties in language learning and teaching as well (Gilakjani, 2012). Pronunciation should be integrated into language classrooms since language competence and performance are directly affected by and ultimately based on pronunciation (Oxford University Press ELT, 2012 and Akyol, 2013). English pronunciation is provided and facilitated to KG kids at early stage since they are natural language acquirers (Dunn, n.d., How young children learn English as another language, para. 1).

Thus, Flipped Demonstration could be used to prepare the KG prospective teachers at the faculty of education for their future career as KG language teachers. It is a mix between Flipped Classroom and Demonstration Method. Flipped Classroom is widely used in higher education to prepare learners for jobs and enable them to master what they learn as well as increase the in-class time for intensive application of the target concepts and skills (Arnold-Garza, 2014). Most studies from 2014 till 2018 which are on the use of flipped classroom in TEFL, were applied in higher education for all language skills as approved in Filiz's \& Benzet's content analysis study (2018).

As a method for presenting practical skills or techniques, demonstration gives the learners the opportunity to see and hear the details 


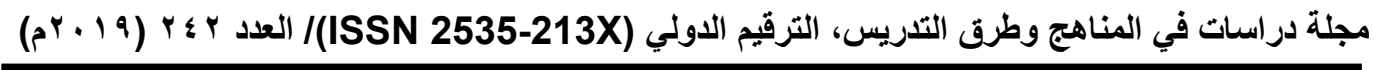

related to the skill being taught as well as perform it for proficiency (Sasi, 2012). It also works perfectly in higher education generally and in teacher education particularly since it improves learners' understanding of complex skills (Tersoo, 2018). So, it is used in combination with flipped classroom since it helps the KG prospective teachers to develop their basic English pronunciation skills as well as improve their performance level for teaching English pronunciation to KG kids.

\section{Context of the problem}

During the researchers' supervision of the Faculty of Education, prospective teachers in the teaching practice at schools, it was noticed that Kindergarten $(\mathrm{KG})$ prospective teachers were unsuccessful when they were assigned by their teaching practice mentors to teach English to KG kids. To figure out the reasons for their inability to teach English pronunciation, open interviews were conducted with $100 \mathrm{KG}$ prospective teachers (50 from $3^{\text {rd }}$ year and 50 from $4^{\text {th }}$ year) at Ismailia Faculty of Education and 18 teaching practice mentors from Ismailia KG Inspectorate.

KG prosepective teachers were asked questions about their ability to teach English to KG kids, the need to develop their English pronunciation and the necessary KG pronunciation teaching techniques. KG Inspectorate members were asked questions about the necessity for KG prospective teachers to teach English, the reasons for their inability to teach English, the need to develop their English pronunciation and their English language skill of lowest performance.

It was revealed that they did not possess the English pronunciation skills nor the practical techniques of teaching English pronunciation to KG kids. Accordingly, they felt inadequate at teaching English in schools and even 


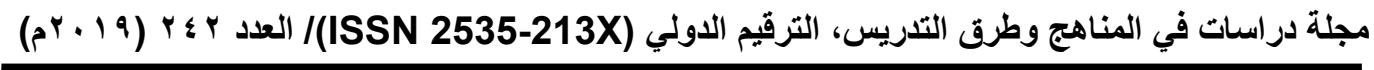

ineligible for teaching English in their future career as $\mathrm{KG}$ language teachers. Also, it was asserted that KG kids' English pronunciation was negatively affected by KG teachers' weak pronunciation and low pronunciation teaching performance level.

For a preliminary investigation to the problem size, two pilot tools were initially administered for $15 \mathrm{KG}$ prospective teachers from each of the four years in the first semester of the academic year 2018-2019: Oral English Pronunciation Test and Performance Observation Sheet for KG English Pronunciation Teaching.

As for the pronunciation test, it was composed of eight questions about reading words, articulation of plurals (s \& es), articulation of possessives \& contractions with final $-\mathrm{S}$, pronunciation of minimal pairs \& past tense verbs, stressing nouns \& numbers as well as uttering questions \& exclamations. It was applied in 50 minutes with $60 \mathrm{KG}$ prospective teachers so that each student was assigned to audio record their spoken responses via their tablets or cell phones. Finally, all recorded audio files were taken on a flash drive for later assessment. The results showed their lack of the basic pronunciation skills.

Regarding the teaching performance observation sheet, it encompassed a six-level gradual scale of performance assessment (Extremely Low $=0$, Low $=1$, Moderate $=2$, High=3, Very High $=4$ and Outstanding=5). It also involved the behaviors for pronunciation teaching (i.e having kids blend and segment sounds). It was applied within three days with $60 \mathrm{KG}$ prospective teachers so that they were divided into two groups of $30 \mathrm{KG}$ prospective teachers. There were three university staff members including the researchers for each group to observe and assess each of the student's 


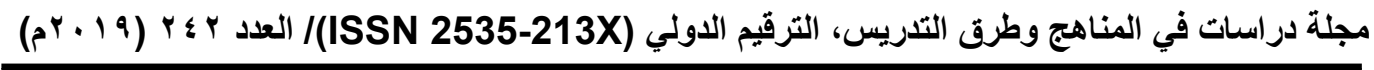

performance during a six-minute task presentation. The results showed their low performance level in teaching pronunciation to KG kids.

Finally, content analysis was conducted to the prescriptions of the English Language courses of the four years, the KG Methods of English Instruction course of the $4^{\text {th }}$ year as well as the Micro-teaching course of the $2^{\text {nd }}$ year for KG department at Ismailia Faculty of Education. It was found out that English language courses do not provide the KG prospective teachers with the pronunciation skills and that the micro-teaching course is completely void of the skills and practical techniques of teaching English pronunciation to KG kids.

Consequently, this study attempted to develop the $\mathrm{KG}$ prospective teachers' English pronunciation and improve their English pronunciation teaching performance level for $\mathrm{KG}$ kids. In this regard, flipped demonstration was used as an integrated pedagogical approach in order to overcome their inadequacy of teaching English in teaching practice at schools and their ineligibility as future language teachers after graduation.

\section{Statement of the problem}

In light of the pilot studies (Content Analysis, Preliminary Pronunciation Exam and Open interviews), KG prospective teachers' English pronunciation inadequacies and low English pronunciation teaching performance level at Ismailia Faculty of Education are critical hurdles which they encounter when assigned to teach English to KG kids at schools during the teaching practice.

\section{Questions}

The research sought to find answers to the following questions: 


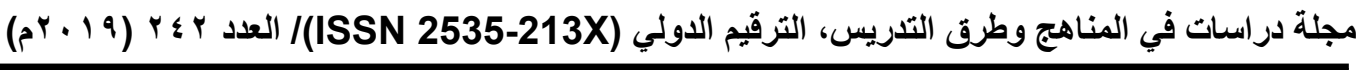

1. What are the English pronunciation skills mostly needed by the $2^{\text {nd }}$ year KG prospective teachers?

2. What are practical techniques of teaching English pronunciation necessary for the $2^{\text {nd }}$ year KG prospective teachers?

3. What are the features of the proposed Flipped Demonstration program?

4. What is the effect of applying the proposed program on the $2^{\text {nd }}$ year $\mathrm{KG}$ prospective teachers':

a. English pronunciation skills?

b. Practical techniques of teaching English pronunciation to KG kids?

5. To what extent is the proposed flipped demonstration program beneficial to KG prospective teachers?

\section{Hypotheses}

1. There is a statistically significant difference between the mean scores of the KG prospective teachers' Micro Pronunciation Skills in the preand post-administrations of part one in the Pronunciation Skills Test in favor of the post-administration.

2. There is a statistically significant difference between the mean scores of the KG prospective teachers' Macro Pronunciation Skills in the preand post-administrations of part two in the Pronunciation Skills Test in favor of the post-administration.

3. There is a statistically significant difference between the mean scores of the KG prospective teachers' overall Pronunciation Skills in the preand post-administrations of the Pronunciation Skills Test in favor of the post-administration. 


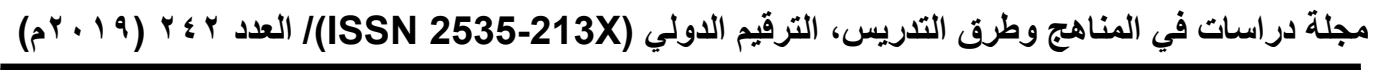

4. There is a statistically significant difference between the mean scores of the pre- and post-administrations of the Pronunciation Teaching Performance Observation Sheet in favor of the post-administration.

5. The Flipped Demonstration program has a high positive effect on KG prospective teachers' English pronunciation learning and teaching.

\section{Aims}

1. Developing the $2^{\text {nd }}$ year $K G$ prospective teachers' English pronunciation skills that are mostly needed by them in their future career as language teachers to KG kids.

2. Improving the $2^{\text {nd }}$ year $\mathrm{KG}$ prospective teachers' English pronunciation teaching performance.

\section{Delimitations}

The current research was delimited to the following:

1. $2^{\text {nd }}$ year KG prospective teachers at Ismailia Faculty of Education in Suez Canal University in Egypt.

2. The basic English Pronunciation Skills that are mostly needed by KG prospective teachers according to literature review and jury's views:

a. Segmental features (Consonants,vowels, diphthongs, final"s,es,ed")

b. Supra-segmental features (Linking, elision, intonation and stress)

3. The Teaching Techniques that are necessary for the KG prospective teachers to teach English Pronunciation to $\mathrm{KG}$ young learners according to literature review and jury's views:

a. Speech production (Explanation \& Modeling Techniques)

b. Speech performance (Controlled, Guided and Free Practice Techniques) 


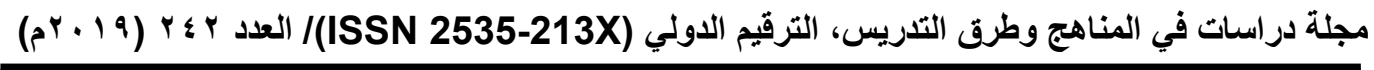

c. Speech assessment (Conformational, Explanatory and Corrective Feedback Techniques)

\section{Method}

1. Participants:

$722^{\text {nd }}$ year KG prospective teachers who enrolled at Ismailia Faculty of Education in the academic year 2018-2019. They were all females whose age ranged between 18 and 19 years old. Resitters were excluded. The reason for this sample selection was to prepare them to teach English in the teaching practice at schools in the $3^{\text {rd }}$ and $4^{\text {th }}$ years since this research aimed to develop their pronunciation skills and improve their pronunciation teaching performance. The sample was divided into two groups (36 for each) so that each researcher had a team work of two staff members to work with a group for mentored performance and assessment.

2. Instruments:

Three instruments were administered in six days of a week before the treatment and in six days of a week after the treatment:

a. English Pronunciation Skills Test (Prepared by the researchers)

To check the validity of this test, a checklist was submitted to a jury committee of university TEFL staff members to verify the test items' representation of the intended learning outcomes. This checklist presented the intended learning outcomes accompanied by their related test items, and a three-level scale of consistency (Inconsistent, consistent and very consistent) between each of the intended learning outcomes and their test items. As for the test reliability, Alpha $(\alpha)$ formula was used in order to 


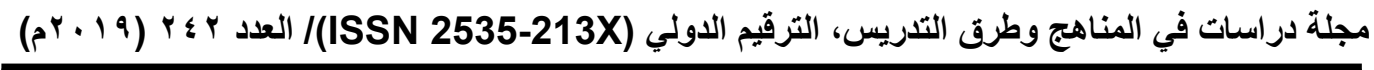

estimate the reliability coefficient. The reliability coefficient was $(86.4 \%)$ for the Pronunciation Skills test. Thus, the test reliability was established.

The estimated time of this test is one hour. It is an oral test. It is composed of two parts: part one for micro pronunciation skills and part two for macro pronunciation skills. It was individually administered before and after the treatment by having each participant record her responses on her own digital device (Tablet, Cell Phone or Laptop) in the lecture hall at the faculty. Such orally recorded responses, in the form of saved audio files, were collected by the researchers for later assessment.

b. Performance Observation Sheet for KG English Pronunciation Teaching (Prepared by the researchers)

To check the validity of this observation sheet, it was submitted to a jury committee of university TEFL staff members to provide their viewpoints for the the measurability of the behaviors underneath the practical techniques of teaching English pronunciation to KG kids as well as the relation between each of the target pronunciation teaching techniques and the behaviors included.

As for the reliability of the observation sheet, the method of Inter-rater Reliability was adopted. The two researchers with a university TEFL staff member as a third observer used this observation sheet to evaluate the same observed behaviors of ten $2^{\text {nd }}$ year $\mathrm{KG}$ prospective teachers provided that the observers began and ended each of the five observations together as well as used the same scale for evaluating the performance. The observers analyzed the data and scored the marks separately. Cooper's formula was used in order to estimate the reliability coefficient. The value of the 


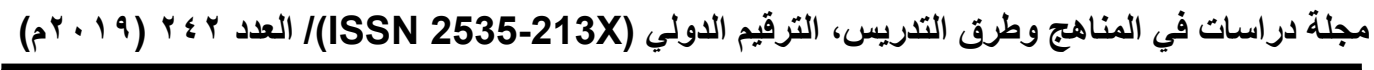

reliability coefficient was $(85.2 \%)$. Thus, the reliability of the observation sheet was established.

The observation sheet encompasses a six-level gradual scale of performance assessment (Not observed $=0$, Poor $=1$, Fair $=2$, Good $=3$, Very Good=4 and Excellent=5). The grading system in this observation sheet is the same as the Teaching Practice Grading System at Ismailia Faculty of Education (Poor $<60 \%, 60 \% \leq$ Fair $<70 \%, 70 \% \leq$ Good $80 \%>, 80 \% \leq$ Very Good $>90 \%$ and Excellent $\geq 90 \%$ ). It also involves the behaviors included in each of the target pronunciation teaching techniques underlying three main stages of Speech Production, Speech Performance and Speech Assessment.

It was individually administered by having each of the participants use the target pronunciation teaching techniques in a 15-minute lesson presentation. The participants were divided into two groups of $36 \mathrm{KG}$ prospective teachers so that there were three university staff members for each group to observe and assess each of the participants' performance during the presentations before and after the treatment. The participant's score was the mean scores of the three raters.

c. Open Interviews (Administered by the researchers)

Open interviews were conducted at the end of the treatment to gather data for qualitative analysis. These interviews aimed to figure out to what extent KG prospective teachers were satisfied with the flipped demonstration program and how it was beneficial for them. In such interviews, participants were asked questions regarding their motivation for learning, use of time, reaching the required materials, learning the content of the provided materials before the class, flipped demonstration's effect on 


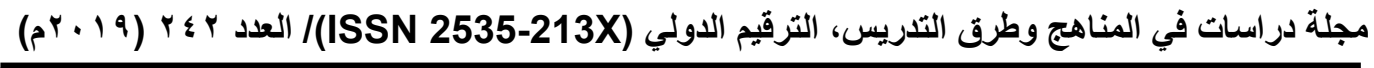

learning and how useful the proposed flipped demonstration program for their future career as KG teachers of English. All the participants enrolled in the current study responded to the interviews.

3. Design:

a. Quasi-experimental method (One Group Pre and Post Test Design) was used to test the hypotheses.

b. Descriptive method was used for literature review as well as the discussion of findings and analysis of data collected from open interviews.

\section{Review of literature and related studies}

\section{English Pronunciation}

\subsection{Pronunciation Learning}

This section tackled the English pronunciation features in order to find out the skills that are mostly needed by KG prospective teachers to teach English to KG kids properly without inflicting drawbacks on KG kids' language learning. English pronunciation features make up the production of sounds and should be introduced to English language learners for practice rather than analytical description for professional reasons (Katz, 2013, p.3 and Bear, 2018). Such features reflect the skills that represent the foundation of good pronunciation (Adult Migrant English Program Research Centre, 2002, p.2).

According to Gilakjani (2012), there are two main features for English pronunciation: Segmental Features and Suprasegmental Features. These basic features are necessary for proper speech production. Segmental features focus on the phonemic awareness since they are closely related to phonemes (consonant sounds and vowel sounds). On the other hand, suprasegmental 


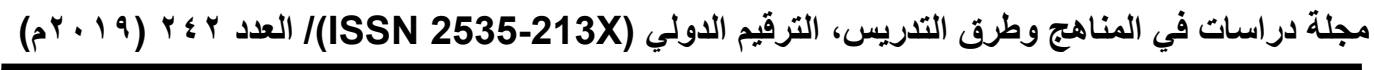

features focus on phonological awareness at the word level (Word Stress) or sentence level in connected speech (Sentence Stress, Linking and Intonation).

In a study for developing pronunciation of young learners, Tomčíková (2006) refers to the additional features of "Triphthongs" for vowel sounds in segmental features, stressed syllables for stress in suprasegmental features as well as "Assimilation" and "Elision" in the suprasegmental features. As an aspect of connected speech, Roach (2012, pp. 107-110) talks about rhythm as an essential suprasegmental feature for English speakers to be understood, showing that rhythm comes is combined with syllable stress \& word stress.

In light of the reviewed pronunciation features, an inventory of the English pronunciation skills was initially prepared and submitted to a jury committee in the fields of TEFL \& KG Curricula to select the skills mostly needed by KG prospective teachers. After modifications, the following are the basic pronunciation skills that should be developed to $\mathrm{KG}$ prospective teachers:

1. Micro Skills (Segmental Features for pronouncing phonemes)

a. Articulating the voiced and voiceless consonants.

b. Articulating the short and long single vowels.

c. Articulating Diphthongs.

d. Pronouncing the finals --s \&--es in plurals, contractions, verbs in third person and possessive cases.

e. Pronouncing --ed in past-tense verbs $\&$ past-participle adjectives.

2. Macro Skills (Supra-segmental Features)

a. Linking the last sound of a word to the first sound of the next word.

b. Dropping the sounds $/ \mathrm{t} /, \mathrm{d} /$ and $/ \mathrm{h} /$ (Elision).

c. Going up and down with the voice according to the context and meanings of communication (Intonation).

d. Emphasizing the syllables with the primary stress in words. 
e. Giving prominence to content words (main verbs, nouns, adjectives, adverbs, negatives, wh questions $\&$ interjections) in an utterance.

f. De-stressing function words (articles, conjunctions, prepositions, pronouns and auxiliaries) in an utterance.

\subsection{Pronunciation Teaching}

This section is to review the English pronunciation teaching techniques in order to identify the practical techniques that are appropriate for $\mathrm{KG}$ kids and necessary for the $\mathrm{KG}$ prospective teachers to acquire as $\mathrm{KG}$ language teachers. There are a number of practical pronunciation teaching techniques. Systematic synthetic phonics (explicit phonics) is a phenomenally effective teaching technique that works for all kids to help them convert graphemes into phonemes and blend that together to read words (Reid, 2016 and ReadingByPhonics.com, n.d.). Also, Phonics Through Spelling is a successful technique in which learners are taught to spell phonemically by segmenting words into phonemes and select letters for those phonemes (National Reading Panel, n.d.).

As for teaching letter sounds, the Montessori Method is recommended to teach letter sounds to children rather than letter names since letter names are useless when reading or writing (Melissa, 2012). In this method, each sound of each letter is introduced isolated as completely as possible. For instance, B does not make the sound "buh", however it makes simply b as there is no "uh" in ball or baby.

All learners' senses should be addressed when teaching pronunciation (Laroy, 2008). Accordingly, Celce-Murcia, Brinton \& Goodwin (2006, pp. 295-299) tackle the technique of Multisensory Modes in which the teacher uses four types of reinforcement. Visual 


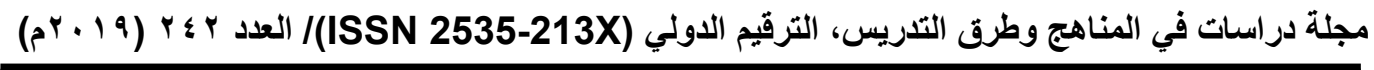

reinforcement that supports what learners can see such as flashcards, sketches and wall charts (Odisho, 2014, pp.200-201 and Reid, 2016). Auditory reinforcement is created through repetition by listening and imitating (Reid, 2016 and Bodorík, 2017). Tactile reinforcement asserts the sense of touch like touching throat to feel vibration of vocal cords. Kinesthetic reinforcement is made by body movements such as using hands to make a mouth model.

As an extension to the Kinesthetic reinforcement, Exaggeration of Articulation is a pronunciation teaching technique in which the teacher emphasizes the movements that are made and the sounds that are produced so learners can imitate or notice the difference such as producing the sound /p/ (Avery \& Ehrlich, 2013, pp. 209-212 and Reid, 2016).

For cognitive orientation, Minimal Pairs is one of the pronunciation teaching techniques in which the teacher demonstrates the production of individual sounds by using pairs of words (Avery \& Ehrlich, 2013, pp. 207-209, Odisho, 2014, p.200 and Reid, 2016). As a support to the use of technology, Celce-Murcia, Brinton \& Goodwin (2006, pp. 311-315) discuss the Computer-Assisted Instruction in which the teacher uses a multimedia element such as video to enhance pronunciation teaching.

As a communicative teaching of pronunciation Laroy (2008, pp.9-10) and Lane \& Brown (2010, pp. 95-168) tackle the pronunciation teaching technique of Integration. In this technique, teachers can integrate intonation work as well as pronunciation of phonemes with other language skills in the classroom such as speaking and writing. As illustrated by Nunan (2003, pp.114-115), this can be accomplished by selecting the pronunciation features to be introduced in communicative language tasks within authentic contexts involving many occurrences of the target 
features. Authenticity refers to the teacher's use of authentic materials such as native speaker voices and realia with letters or words to read (CelceMurcia, Brinton \& Goodwin, 2006, pp. 299-305).

In this regard, Martin (2013, pp. 28-32) explains the practical procedures. First, teacher explains how a new pronunciation feature is produced. Second, teacher provides a listening practice for discrimination. Third, teacher gives controlled practice to monitor the new pronunciation features in oral production. Fourth, guided practice is administered for semi-structured exercises with progress monitoring. With reference to the role of repeated reading in teaching pronunciation, Gil, De Larios, \& Balibrea (2017) refers to the positive impact of repeated reading on the improvement of EFL young learners' pronunciation.

Finally, leaners go through a free communicative practice mentored by the teacher. In a study by Gilakjani (2016), coaching technique facilitates pronunciation teaching. As a coach, the teacher provides a speech production for the pronunciation feature followed by learner's speech performance which, in turn, is monitored and assessed by the teacher (Nunan, 2003, pp.116-117 and Gilakjani, 2016).

Based on literature review for the techniques of teaching English pronunciation, a checklist was initially prepared and submitted to jurors in the fields of TEFL \& KG Curricula to choose the most appropriate practical pronunciation teaching techniques to $\mathrm{KG}$ kids. After doing modifications, a proposed strategy of practical techniques, was used by KG prospective teachers when teaching English pronunciation to KG kids in order to improve their teaching performance level as shown in the following figure: 


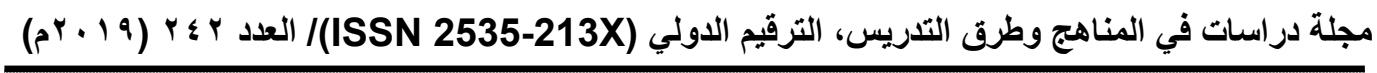

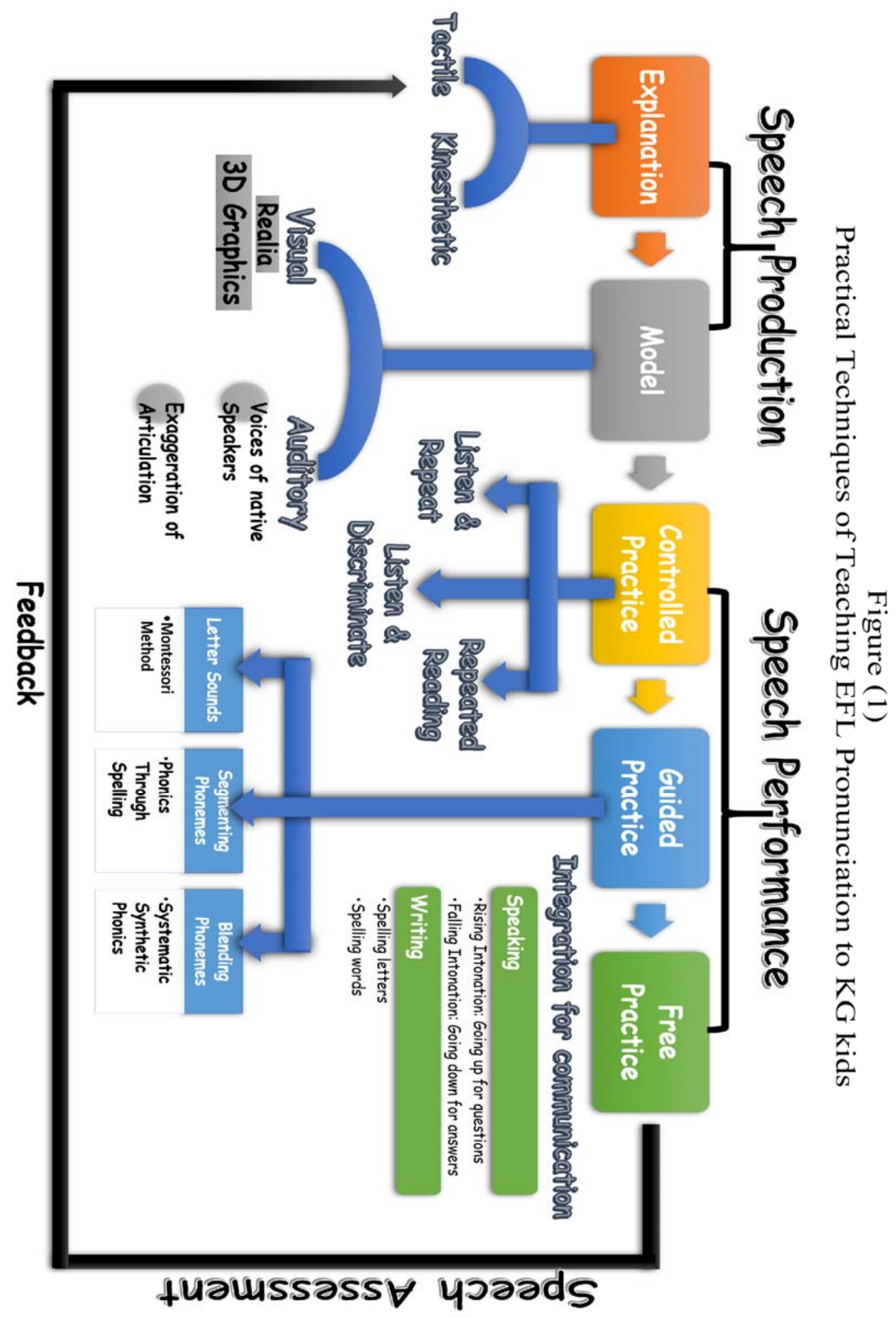




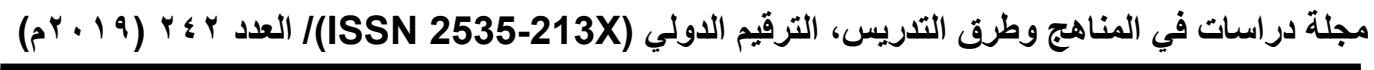

According to the figure, there are three stages with their inherent pronunciation teaching techniques so that each of such techniques has its own procedures as follows:

1. Speech Production

In this stage, the KG teacher gives demonstrative production for the target pronunciation feature to the kids by following two techniques: Explanation and Modeling. First, the KG teacher explains how the pronunciation feature is produced and reinforces the explanation by helping the kids use the tactile and kinesthetic sensory modalities. In the tactile reinforcement, kids are encouraged to use the sense of touch. In the kinesthetic reinforcement, kids are asked to make movements such as moving the tongue between the teeth in the sound $/ \Theta /$. Also, the $K G$ teacher uses the kinesthetic sensory modality to make the form of mouth with her hands when explaining the production of vowels.

Second, KG teacher's modeling is supported by visual and auditory sensory modalities. In the visual reinforcement of the model, real visual aids are used so that kids read the letters or words on them. In the auditory reinforcement, recorded native speakers' voices are used. Also, articulation of pronunciation features should be exaggerated by the $\mathrm{KG}$ teacher to focus kids' attention on basic parts of articulation.

\section{Speech Performance}

In this stage, $\mathrm{KG}$ kids are allowed to perform and produce the target pronunciation feature through three successive phases of practice: Controlled Practice, Guided Practice and Free Practice. In controlled practice, KG kids stick to a pattern while practicing the target pronunciation feature. Three practical techniques can be used in this phase: Listen \& Repeat, Listen \& Discriminate and Repeated Reading. In the 


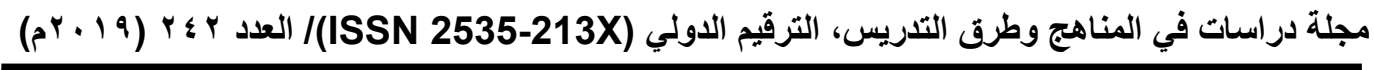

technique of listen \& repeat, kids orally repeat after the $\mathrm{KG}$ teacher or a recorded speech until mastery. In the technique of listen $\&$ discriminate, the minimal pairs can be used to help the kids figure out the nuances in the production between two different sounds in a pair of three letter words which are only different in one letter. In repeated reading, kids repeat the letters or words they read until they reach the satisfactory reading speed.

In guided practice, KG kids follow a pattern while practicing the target pronunciation feature. Three practical techniques are used in sequence to help kids start learning easier pronunciation skills and move on to harder ones. At the beginning, Montessori Method is used to help the kids correlate the letters with their sounds. Then, the technique of Phonics Through Spelling is used to help the kids segment the words into separate sounds for spelling. Finally, the technique of Systematic Synthetic Phonics is used to make the kids read words by blending sounds.

In free practice, the integration technique is used to help the kids practice pronunciation for communication orally or in writing. To integrate pronunciation with speaking, kids practice pronunciation for communication by asking (rising intonation) and answering questions (falling intonation) orally. To integrate pronunciation with writing, kids practice pronunciation for communication by dictation of letters or words.

3. Speech Assessment:

In this stage, KG kids' production of the target pronunciation feature is monitored and checked by the teacher. Here, immediate corrective and constructive feedback is provided. Conformational, Explanatory and Corrective feedback is given instantly after KG kids' responses during their controlled, guided and free practice. KG teacher can start over again with the kids if necessary. 


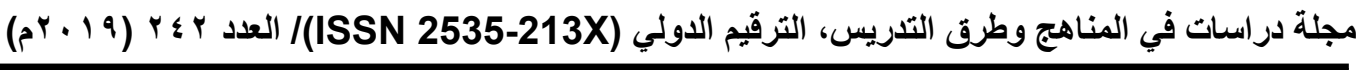

\section{Flipped Demonstration}

\subsection{Flipped Classroom}

\subsubsection{Definition}

According to Wolff and Chan (2016) and Higher Education Academy (2017), flipped classroom is a pedagogical approach in which learners are introduced to the learning material before the class so that their class time is used for in-depth understanding through individual and peer interactive activities facilitated by the teacher. In their definition, Abeysekera \& Dawson (2015) refer to the different flipped classroom patterns before the class which can be online discussions among learners or between learners and the instructor, digital research, videos or presentations by third parties other than the instructor and text reading.

Flipped classroom can be operationally defined as "A pedagogical approach that supports collaborative discussions online or face-to-face among KG prospective teachers and delivers them the multimedia instructional content before the class to get prepared for in-class mentored performance by learning the pronunciation features necessary for performing the target pronunciation skills as well as the practical techniques of teaching pronunciation to KG kids".

\subsubsection{Benefits}

As a pedagogy in higher education, flipped classroom causes shift in teacher's role from presenter to facilitator, increase of class attendance as well as better grades in achievement (Higher Education Academy, 2017). It replaces routine lectures with group and individual in-class activities that make learners responsible for what they learn (Rosenberg, 2013). This is in line with the studies that were conducted by Alsowat (2016), Zainuddin 


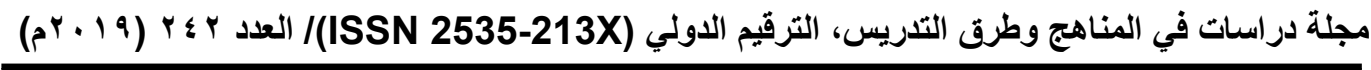

(2017), Chen Hsieh, Wu, \& Marek (2017), Lin \& Hwang (2018) as well as Sağlam \& Arslan (2018). The findings pointed out that flipped classroom had a higher positive effect on university learners' achievement, engagement, satisfaction and attitudes towards EFL courses.

As a method for mastery, flipped classroom provides learners with the content gist before class in order to save in-class time for their intensive practice of the new concept or skill with the teacher's presence as a facilitator (Pappas, 2012; Mehring, 2016 and Acedo, 2018). This also goes with Ahmad's study (2016) that aimed to develop Egyptian EFL university learners' listening comprehension. Flipped classroom leads learners to master the intended learning outcomes (ILOs) in EFL contexts as verified in Webb's \& Doman's study (2016). Mastery learning is also ensured so that learners cannot move on to another concept or skill until they have demonstrated understanding and shown progress (Arnold-Garza, 2014).

As a tool of diagnosis, flipped classroom can help the teacher to quickly identify the difficulties faced by those learners who have problems with learning the content (Pappas, 2012 and Bergmann \& Sams, 2014). This way, it promotes one on one instruction with the learners who need extra help (Acedo, 2018). Individual differences are considered and differentiation is allowed since learners can also learn at their own pace and they have the ability to re-watch, re-listen and reread the learning materials for reviewing without wasting the in-class time (Bergmann \& Sams, 2014 and Mehring, 2016).

\subsubsection{Flipped Classroom Model}

Filiz \& Benzet (2018) explain two main stages for flipped classroom to invert: Outside-Class stage for content acquisition and In-Class stage 


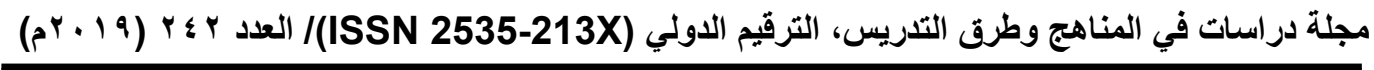

content application. In the Outside-class stage, learners gain knowledge before class time and get themselves prepared for class activities by watching videos, doing quizzes or mini tests prepared by the instructor as well as by using learning management systems such as online discussions.

In the In-class stage, learners get involved in activities to practice applying the key concepts with feedback and guidance from their instructor during the class time. In-class time can also be used for enabling learners to understand the difficult knowledge when necessary (Boyraz, \& Ocak, 2017). In their studies for developing EFL flipped classroom models, Ahmad (2016) and Alsowat (2016) add a planning stage where content preparation (stating objectives and designing / selecting the materials) and class orientation (delivering the instructional materials) take place.

Texas Faculty Innovation Center (2013) introduces "After Class" as a third stage outside the class for reflective practices. In this stage, learners check their understanding deeper and extend their learning after the class since they leave the class with a greater collection of resources and a clear awareness with what they need to focus on to close any gaps that may remain in their learning.

\subsubsection{Flipped Classroom and Pronunciation}

Flipped classroom enhances linguistic competence of pronunciation in language skills. In Koroglu's \& Cakir's study (2017), it was significantly approved that flipped classroom developed pre-service English Language teachers' speaking skills in terms of accuracy and pronunciation skills. Also, flipped classroom was proved to be effective in a study aimed at enhancing the oral proficiency of university EFL learners through highly 


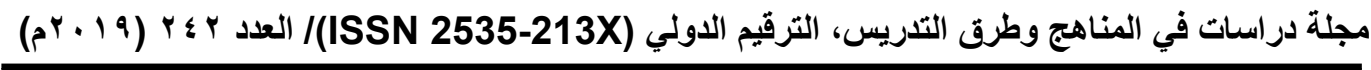

interactive learning activities in pronunciation, storytelling, discussion, conversation and oral group presentation (Wu, Hsieh, \& Yang, 2017).

Flipped Classroom allows for learners' use of digital technology whether online or offline to learn pronunciation. Online pronunciation learning was proved to be effective in Cunningham's study (2015) that aimed at delivering an online course (i.e. web-based English articulation of sounds on BBC Learning English website) to improve the English pronunciation of the Swedish primary school teachers of English who were non-specialist of English. Moreover, using mobile technologies in flipped classroom makes English teaching successful as shown in Obari's \& Lambacher's case studies (2015) that revealed flipped classroom's high impact on students' oral proficiency at a private university in Tokoyo. refers to the vital role of self-monitoring that should be an integral part.

When applying flipped classroom, self-monitoring can be incorporated while learning pronunciation skills inside and outside the classroom as recommended by Kenworthy $(1988,118)$. In this case, KG prospective teachers can assess their pronunciation skills and pronunciation teaching performance by the use of their available digital devices and replaying their recorded speech and performance outside the classroom.

\subsection{Demonstration}

\subsubsection{Definition}

Sasi (2012) and Francisco (2017) define demonstration as verbal explanation supported by live display and/or use of apparatus. In his definition, Tersoo (2018) refers to the explanation as audio display (verbal information) and to the experiments or examples following the explanation as performance (visual information). Demonstration can be procedurally 


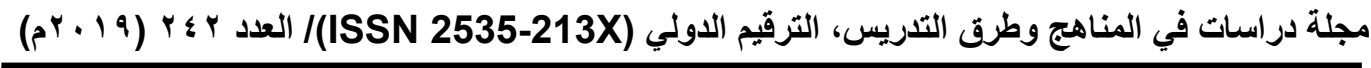

defined as "A teaching method that provides $\mathrm{KG}$ prospective teachers with audio-visual explanatory models for the English pronunciation skills and the KG practical techniques of teaching English pronunciation, followed by mentored performance for mastery learning".

\subsubsection{Demonstration Model}

Mangade (2010) illustrates in a Youtube video, the following five essential phases for demonstration:

1. Explanation: Describing the steps and criteria for skill performance

2. Modeling: Acting accurately to show how the skill is performed

3. Learner's Performance: Asking learners to perform the skill.

4. Instructor Supervision: Monitoring learners' progress while coaching them to make sure that they follow the steps in light of the criteria.

5. Evaluation: Judging learners' performance by testing their ability to perform without assistance to check out their learnt skills.

\subsubsection{Demonstration and Pronunciation}

It is generally recognized that the demonstration method has been proved to be effective when teaching a skill-type subject matter as indicated in Husnu's study (2018). In this study, effectiveness was established when demonstration was examined to solve problems in learners' English speaking by improving vocabulary, grammar and pronunciation. In Moedjito's study (2018) for the reappraisal of EFL pronunciation teaching, it was revealed that using demonstration supported by quizzes, practice and revision was significantly correlated to teaching English pronunciation and, in turn, helpful in improving EFL pronunciation for university learners enrolled at the Department of English Language Education. Negru, Juica and Stojanovic's study (2016) claims that demonstration as an effective teaching method for Language pronunciation could support in developing personal career teacher. Therefore, it was utilized in the present study for developing KG prospective 


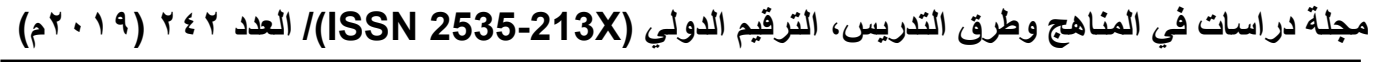

teachers' English pronunciation skills and improving $\mathrm{KG}$ prospective teachers' pronunciation teaching performance.

\subsection{Flipped Demonstration as an integrated pedagogical approach}

\subsubsection{Definition}

When flipped classroom is combined with demonstration, flipped demonstration can be defined as "An integrated pedagogical approach in which KG prospective teachers are allowed before the class to answer digital quizzes, participate in collaborative discussions and peer assessment and tutoring (online or face-to-face) as well as learn the provided multimedia based explanations and audio-visual models for the English pronunciation skills \& the KG practical teaching techniques of English pronunciation (outside-class phase) to get engaged actively during the class mentored performance for mastery learning (in-class phase)“.

\subsubsection{Rationale}

Integrating flipped Classroom with demonstration is recommended since such combination solves critical problematic pedagogical issues when using the demonstration method or flipped classroom solely to introduce the pronunciation skills or the practical techniques of teaching pronunciation.

First, demonstration is not effective and becomes a failure in case of classes with a great number of learners (Sasi, 2012). It usually takes much time to explain the theoretical knowledge (criteria and steps) and give models for the practical skills or techniques since some learners often ask for repetition. This, in turn, delays learners' progress because it decreases the time allotted for their performance of the target skills or practical techniques (Francisco, 2017). Consequently, it inflicts drawbacks on learners' direct experience of interaction. Using flipped classroom with demonstration helps learners study the provided explanations and models individually outside the 
class at their own learning pace. Thus, they can be ready for practical performance and make the best use of the whole time allotted in the class.

Second, demonstration allows learners to have the direct experience of interaction only during their performance of the target skills or practical techniques. No discussions or interactions are allowed during the explanation or modeling of the skill (Tersoo, 2018). When combining it with flipped classroom, learners can have such experience by peer tutoring as well as through online collaborative discussions. They can also interact with the theoretical content of explaining and modeling the skill or the practical technique through the use of the digital technology which is personally available outside the classroom.

Third, demonstration can be hardly administered in classes which are scarcely equipped with the necessary audio-visual aids and multimedia digital technology for learning the target skills or practicing the required techniques (Farooq, 2013 and Francisco, 2017). However, blending flipped classroom with demonstration allows learners to use the digital devices available outside the class; such as PC, mobile, laptop or tablet at home.

Fourth, in flipped classroom, trust is hardly given to the learners when the instructor relies on them to study the learning materials, gain the required knowledge and get prepared before the class for the performance of the target skills (Acedo, 2018). Therefore, it should be integrated with demonstration since demonstration focuses on learners' performance of the skill. This, in turn, motivates the learners to get prepared before the class by showing some progress with their skill performance during the class. The following tables shows how this integrated pedagogical approach makes benefit from combining flipped classroom with demonstration. 
Integration of Flipped Classroom and Demonstration

\begin{abstract}
Flipped Classroom
Independence and Individual Learning:

It enhances self-autonomy learning and selfpacing since learners study the provided materials individually according to their learning speed to ger prepared before class for the performance of the skills and practical techniques.
\end{abstract}

One on One Instruction:

Before and after the class: Leaners can have direct experience by interacting with the digital content of the available materials outside the class.

During the class: Teacher can provide one on one instruction as extra assistance for struggling learners in the class time.

\section{Excellent Diagnostic Tool:}

Teachers can easily get those struggling learners and, in turn, pay more attention to address their weakness in particular.

\section{Use of Technology:}

Facilitating the use of digital technology since learners receive direct instruction before class where personal digital devices (e.g. tablet, PC, cell phone) could be available rather than in the class.

\section{Preparation and Time Save:}

Learners are previously prepared for the target skills or practical techniques before the class. This saves the time for learners' mentored performance.

\section{Content Accessibility:}

The learning materials are available all the time so learners who miss class can easily get them.

\section{Demonstration}

\section{Learners' Performance:}

Leaners can have direct experience by practicing the performance of the target skills or practical techniques.

Feedback \& Performance Assessment: Learners perform the target skills or practical techniques in the class with the attendance of the tutor as a mentor, guide and facilitator. This allows the tutor to judge learners' performance level and progress

\section{Responsibility and Reliability:}

Learners are trusted to gain access to the knowledge required to learn the target skills since they have to perform them in class 


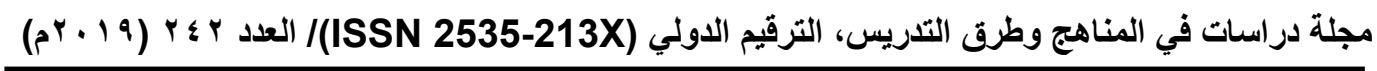

\subsubsection{Flipped Demonstration Framework}

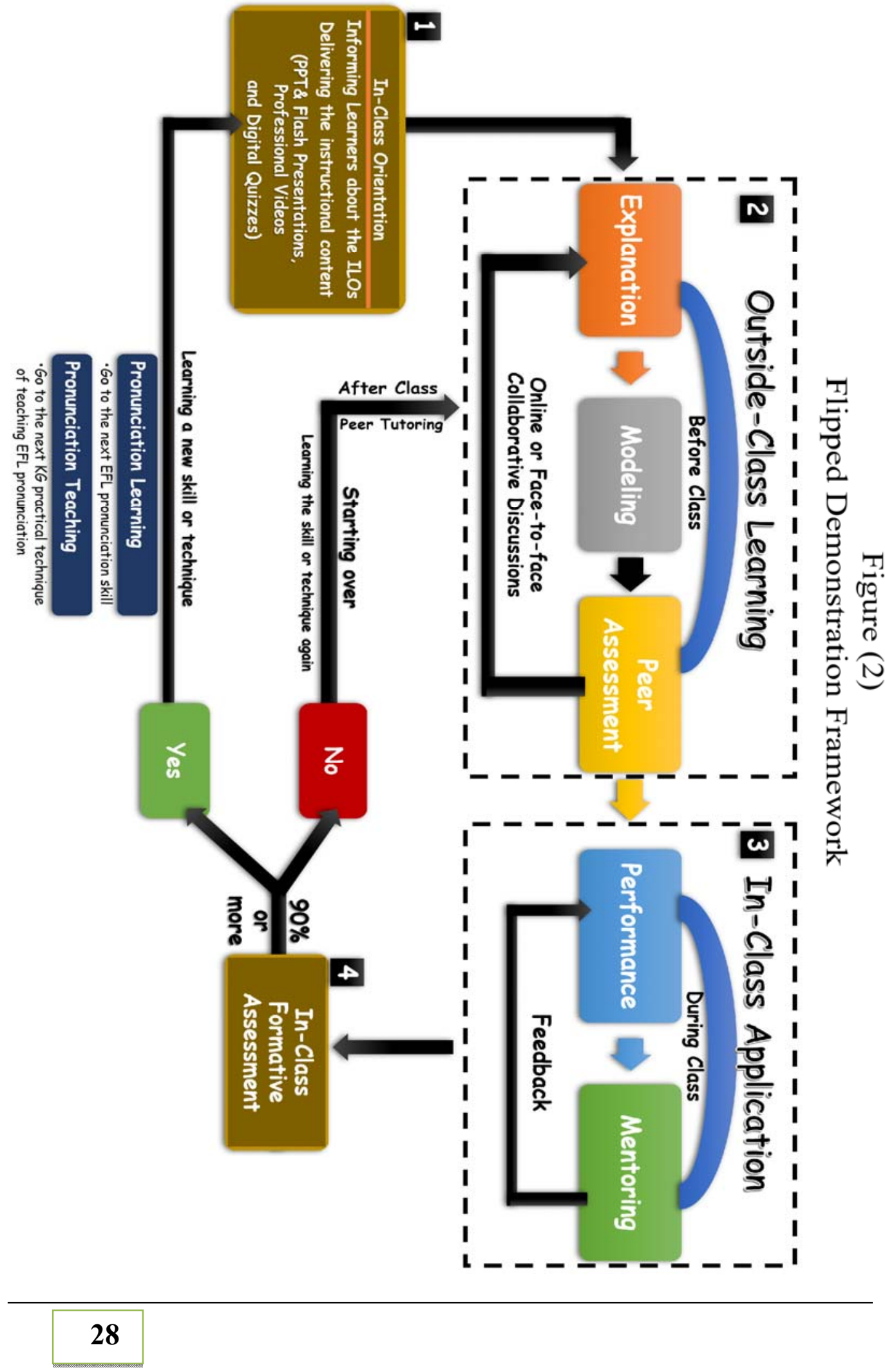




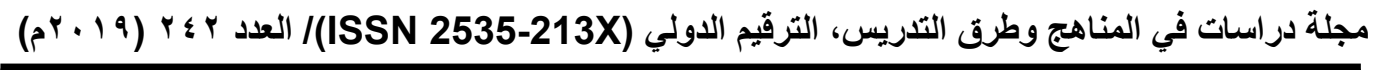

Figure (2) shows that there are four main phases for flipped demonstration as follows:

\section{In-class Orientation:}

This phase aims at providing an introductory session in the class whenever learners start to learn a new English pronunciation skill or practical technique of teaching English pronunciation to KG kids. Here, they can figure out their expectations as well as get the required multimedia instructional content for the outside-class learning. In this phase, the learners are informed about the ILOs. The essential learning materials are also delivered. They are Multimedia PPT/Flash Presentations, Professional Videos for skillful models on the target pronunciation skills or $\mathrm{KG}$ practical techniques of pronunciation teaching and digital quizzes. Such materials can be offered online or offline via flash drive or DVD for those learners who do not have access to the internet. Guidelines for using such materials are also provided.

\section{Outside-class Learning:}

This phase takes place before the class where learners go through three steps: Explanation, Modeling and Peer Assessment. In the explanation, they study the criteria and procedures through PPT/Flash multimedia presentations. In the modeling, they watch the audio-visual explanatory models for performing the target skills or practical techniques. After explanation and modeling, they have online or offline digital quizzes to check their understanding and increase their responsibility for learning. In the peer assessment, they attempt to imitate the models and video-record their initial speech production or teaching performance to be shared with classmates and judged by their peers for mutual feedback. 


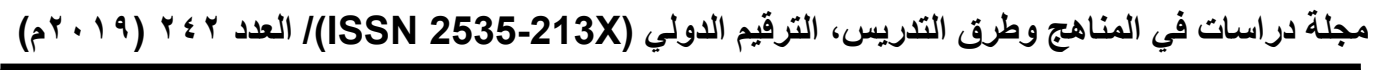

Collaborative discussions are also available face-to-face for those learners who do not have internet access or online via internet and mobile technologies (i.e. WhatsApp, Skype and Facebook). Such discussions aim at exchanging ideas, talking about and reviewing what they have learnt as well as commenting on each other's initially video-recorded responses in order to get themselves well prepared as much as possible for their mentored performance in the class.

\section{In-class Application:}

This phase occurs during the class where learners are assumed to apply what they should have previously learnt via the provided PPT/Flash presentations and the carefully selected professional videos for audio-visual explanatory models outside class. Thus, in-class time is saved for intensive practice and deeply mentored performance. Here, learners produce the target pronunciation features or apply the KG practical techniques of teaching pronunciation. Their performance is followed by the instructor's mentoring via corrective and explanatory feedback. This feedback provides correction for errors in performance and the reasons for mis-practices. Also, learners are allowed to video-record their in-class speech production or teaching performance for self-assessment after the class. Such recordings can also be exchanged after class to provide help by successful learners via discussion and peer tutoring.

For those learners who encountered any problematic issues with grasping the provided instructional content outside the class, in-class time can be allotted for enhancing their understanding and ability to grasp what they learn without delaying the others' progress. 


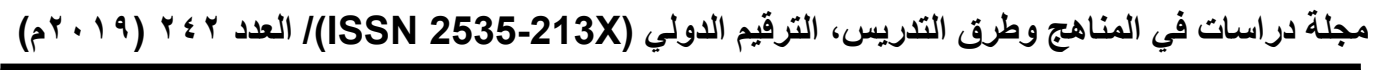

4. In-class Formative Assessment:

This phase follows the in-class application, where participants' oral production of the target pronunciation feature is individually recorded and assessed or their performance of the $\mathrm{KG}$ practical technique of pronunciation teaching is assessed by three raters. Such internal assessment aims to check whether they have reached the mastery level or not. If the learners get $90 \%$ or more, mastery learning is established. In this case, those successful learners move on to learn the next skill or practical technique and go for in-class orientation instantly to be informed about the ILOs as well as get the learning materials for further outside class learning.

If mastery learning is not reached, those unsuccessful learners have to start over again to learn the same skill or technique after the class by studying the previously provided materials again and re-watching the audio-visual explanatory models. In this case, those learners can get help through peer tutoring outside the class to learn and perform the target skill or practical technique again. In peer tutoring, unsuccessful learners watch the personal video-recordings for the in-class mentored performance of their successful peers who manage to reach the mastery level. Unsuccessful learners can discuss the video-recordings of successful classmates with their clever peer tutors. They can also compare these successful video-recorded responses to their unsuccessful in-class ones. 


\section{The Program}

The proposed flipped demonstration-based program involves the following two modules:

\section{Module One}

"English Pronunciation Learning"

1. Segmental Features:

a. Consonants (Voiced \& Voiceless)

b. Vowels (Short \& Long)

c. Diphthongs

d. Finals (s), (es) and (ed)

2. Supra-segmental Features:
a. Linking
b. Elision
c. Intonation
d. Stress (Syllable, Word and Sentence Level)

\section{Module Two}

"KG English Pronunciation Teaching"

1. Speech production:
a. Explanation Technique
b. Modeling Technique

2. Speech Performance:
a. Controlled Practice Techniques
b. Guided Practice Techniques
c. Free Practice Integration Technique

3. Speech Assessment:
a. Conformational Feedback Technique
b. Explanatory Feedback Technique
c. Corrective Feedback Technique

\section{Treatment}

The proposed flipped demonstration-based program was carried out in the first semester of the academic year 2018-2019 with total 71 hours for in-class sessions in 7 weeks as follows:

\begin{tabular}{|c|c|}
\hline \multirow{3}{*}{$\begin{array}{l}\text { Module One } \\
\text { 'English } \\
\text { Pronunciation }\end{array}$} & n October $13^{\text {th }} 2018$ and ende \\
\hline & Three days a week (One or Two in-class sessions per day). \\
\hline & $\begin{array}{l}\text { The content is divided into Six Topics. Each topic has Three in-class } \\
\text { sessions (Orientation session, Application session and Formative } \\
\text { Assessment session). }\end{array}$ \\
\hline Learning” & $\begin{array}{l}\text { (One hour for each in-class orientation session, } \\
\text { ach in-class application session and One hour for } \\
\text { sessment session) }\end{array}$ \\
\hline \multirow{4}{*}{$\begin{array}{l}\text { Module Two } \\
\text { “KG English } \\
\text { Pronunciation } \\
\text { Teaching" }\end{array}$} & rting from November $10^{\text {th }} 2018$ and ended on \\
\hline & ter the last week (Or \\
\hline & $\begin{array}{l}\text { The content is divided into Five Topics. Each topic has Three in- } \\
\text { class sessions (Orientation session, Application session and } \\
\text { Formative Assessment session). }\end{array}$ \\
\hline & $\begin{array}{l}\text { in-class hours (One hour for each in-class orientation session, } \\
\text { ree hours for each in-class application session and Three hours } \\
\text { each formative assessment session) }\end{array}$ \\
\hline
\end{tabular}




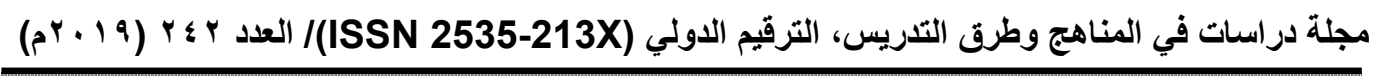

\section{Results}

To answer the fourth question, the hypothses were statistically tested as follows:

Hypothesis I stated "There is a statistically significant difference between the mean scores of the KG prospective teachers' Micro Pronunciation Skills in the pre- and post-administrations of part one in the Pronunciation Skills Test in favor of the post-administration." The paired samples t-Test was used to check this hypothesis. The following table shows the results related to KG teachers' micro pronunciation skills.

\section{Table (2)}

Paired Samples t-Test value of the difference between the mean scores of the micro pronunciation skills in the Pre-and Post-administrations of part one the pronunciation skills test

\begin{tabular}{|l|c|c|c|c|c|c|}
\hline \multicolumn{2}{|c|}{} & N & Mean & $\begin{array}{c}\text { St. } \\
\text { Deviation }\end{array}$ & t & Significance \\
\cline { 1 - 4 } Hypothesis I & Pre-administration & \multirow{2}{*}{72} & 7.527778 & 1.920770 & -40.27 & .000 \\
\cline { 2 - 2 } & Post-administration & & 30.56944 & 4.608096 & & \\
\hline
\end{tabular}

Table (2) shows that there is a difference between the mean scores of the micro pronunciation skills in the Pre-and Post-administrations of part one in the pronunciation skills test. The difference was statistically significant $(\mathrm{t}=-40.27, \mathrm{p}<0.05)$. 


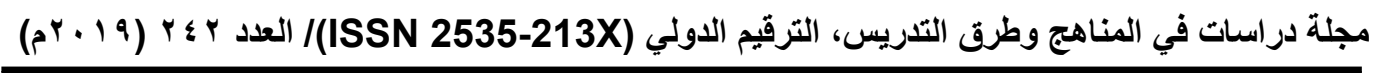

Hypothesis II stated "There is a statistically significant difference between the mean scores of the KG prospective teachers' Macro Pronunciation Skills in the pre- and post-administrations of part two in the Pronunciation Skills Test in favor of the post-administration." The paired samples t-Test was used to check this hypothesis. The following table shows the results related to KG teachers' macro pronunciation skills.

\section{Table (3)}

Paired Samples t-Test value of the difference between the mean scores of the macro pronunciation skills in the Pre-and Post-administrations of part two in the pronunciation skills test

\begin{tabular}{|l|c|c|c|c|c|c|}
\hline \multicolumn{2}{|c|}{} & N & Mean & $\begin{array}{c}\text { St. } \\
\text { Deviation }\end{array}$ & t & Significance \\
\cline { 1 - 4 } Hypothesis II & Pre-administration & \multirow{2}{*}{72} & 2.958333 & 0.941044 & -25.11 & .000 \\
\cline { 2 - 4 } & Post-administration & & 17.02777 & 4.726230 & & \\
\hline
\end{tabular}

Table (3) shows that there is a difference between the mean scores of the macro pronunciation skills in the Pre-and Post-administrations of part two in the pronunciation skills test. The difference was statistically significant $(\mathrm{t}=-25.11, \mathrm{p}<0.05)$.

Hypothesis III stated "There is a statistically significant difference between the mean scores of the KG prospective teachers' overall Pronunciation Skills in the pre- and post-administrations of the Pronunciation Skills Test in favor of the post-administration.”. The paired samples t-Test was used to check this hypothesis. The following table shows the results related to KG teachers' overall pronunciation skills. 
Table (4)

Paired Samples t-Test value of the difference between the mean scores of the overall pronunciation skills in the Pre-and Post-administrations of the pronunciation skills test

\begin{tabular}{|l|c|c|c|c|c|c|}
\hline \multicolumn{2}{|c|}{} & N & Mean & $\begin{array}{c}\text { St. } \\
\text { Deviation }\end{array}$ & t & Significance \\
\cline { 1 - 1 } $\begin{array}{l}\text { Hypothesis } \\
\text { III }\end{array}$ & Pre-administration & \multirow{2}{*}{72} & 10.52777 & 2.257833 & -44.30 & .000 \\
\cline { 2 - 5 } & Post-administration & & 47.73611 & 7.207182 & & \\
\hline
\end{tabular}

Table (4) shows that there is a difference between the mean scores of the overall pronunciation skills in the Pre-and Post-administrations of the pronunciation skills test. The difference was statistically significant $(\mathrm{t}=$ $-44.30, \mathrm{p}<0.05)$.

Hypothesis IV stated "There is a statistically significant difference between the mean scores of the pre- and post-administrations of the Pronunciation Teaching Performance Observation Sheet in favor of the post-administration.". The paired samples t-Test was used to check this hypothesis. The following table shows the results related to KG teachers' pronunciation teaching performance.

Table (5)

Paired Samples t-Test value of the difference between the mean scores of the Pre-and Post-administrations of the Pronunciation Teaching Performance Observation Sheet

\begin{tabular}{|c|c|c|c|c|c|c|}
\hline & & $\mathbf{N}$ & Mean & $\begin{array}{c}\text { St. } \\
\text { Deviation }\end{array}$ & $\mathbf{t}$ & Significance \\
\hline \multirow[t]{2}{*}{ Hypothesis IV } & Pre-administration & \multirow{2}{*}{72} & 6.680556 & 2.944684 & \multirow[b]{2}{*}{-203.7} & \multirow[b]{2}{*}{.000} \\
\hline & $\begin{array}{c}\text { Post- } \\
\text { administration }\end{array}$ & & 80.58333 & 1.350535 & & \\
\hline
\end{tabular}


Table (5) shows that there is a difference between the mean scores of the teaching performance in the Pre- and Post-administrations of the Pronunciation Teaching Performance Observation Sheet. The difference was statistically significant $(\mathrm{t}=-203.7, \mathrm{p}<0.05)$.

Hypothesis V stated "The Flipped Demonstration program has a high positive effect on KG prospective teachers' English pronunciation learning and teaching". The effect size $\left(\eta^{2}\right)$ was estimated to check this hypothesis. The following table shows the values of $\left(\eta^{2}\right)$ for KG prospective teachers' pronunciation learning and teaching:

Table (6)

The Effect Size level of flipped demonstration on KG prospective teachers' English pronunciation learning and teaching

\begin{tabular}{|c|c|c|c|c|c|c|}
\hline $\begin{array}{c}\text { Independent } \\
\text { variable }\end{array}$ & \multicolumn{2}{|c|}{ Dependent variable } & $\mathbf{t}^{2}$ & DF & $\eta^{2}$ & $\begin{array}{c}\text { Effect } \\
\text { Size }\end{array}$ \\
\hline \multirow{4}{*}{$\begin{array}{c}\text { Flipped } \\
\text { Demonstration }\end{array}$} & \multirow{3}{*}{$\begin{array}{c}\text { English } \\
\text { Pronunciation } \\
\text { Learning }\end{array}$} & Micro & 1622.38954 & \multirow{4}{*}{71} & 0.95 & High \\
\hline & & Macro & 630.61410 & & 0.89 & High \\
\hline & & Overall & 1962.49 & & 0.96 & High \\
\hline & \multicolumn{2}{|c|}{$\begin{array}{c}\text { English Pronunciation } \\
\text { Teaching }\end{array}$} & 41493.6 & & 0.99 & High \\
\hline
\end{tabular}

According to table (6), Eta-squared was used to calculate the effect size of flipped demonstration on $\mathrm{KG}$ prospective teachers' English pronunciation learning and teaching. The effect sizes were high $\left(\eta^{2}=0.95\right.$, 0.89, 0.96 and 0.99); therefore, the flipped demonstration program had a high positive effect on KG prospective teachers' English pronunciation learning and teaching. 


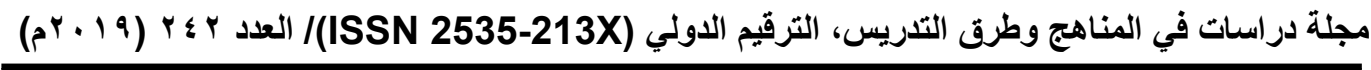

\section{Discussion of results}

The results of the present study may be due to the following reasons. Flipped classroom allowed the participants to learn the content by watching videos and using PPT/Flash presentations before the class so that they were ready for interactive mentored practice during the class. In spite of having the instructional content outside the class, participants had to study it since they had to answer the digital quizzes before class and get prepared for mentored performance as an essential phase in the demonstration method during the class. This is the same reason for the successful implementation of flipped classroom model in Ahmad's study (2016) in which the Egyptian EFL university students were allowed to watch online videos and use PPT lectures before the class so that they were ready for in-class practice.

By having the content before the class, individual differences were considered regarding participants' preferences for individual or group learning as illustrated by Bergmann \& Sams (2014). Materials were provided before class for self-autonomy. However, discussions and peer tutoring were available online through PC, Tablet, Laptop or Mobile technologies for group learning as shown in Obari's \& Lambacher's case studies (2015) as well as Wu's, Hsieh's, \& Yang's study (2017).

In flipped classroom, online video resources were provided for powerful native speakers of English explaining and displaying professional models for the target English pronunciation skills. This explained why KG prospective teachers managed to overcome the problems of fossilized mispronunciation. Also, online video resources were utilized for highly experienced $\mathrm{KG}$ teachers modeling the practical techniques of teaching pronunciation to KG kids skillfully. Moreover, the technical features of the 


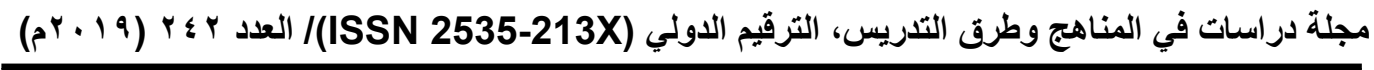

video navigation control panel (pausing, stopping, rewinding, speed controlling for fast or slow motion) that helped the participants to scrutinize the detailed physical features for the production of pronunciation skills as well as the procedural display for the performance of the $\mathrm{KG}$ practical techniques of teaching English pronunciation. Accordingly, participants' deep understanding for mastery learning of the target skills and practical techniques was established.

Flipped classroom changed instructor's role from a presenter to a facilitator as claimed by Higher Education Academy (2017). Online collaborative discussions and peer tutoring among the participants supported their active learning before the class and, in turn, helped them figure out their points of weakness and strength. Flipped classroom worked well with a class of a large number of learners as claimed by Sasi (2012) and Francisco (2017). In-class time was used for enabling participants to overcome any difficulties for understanding the instructional content provided outside class without delaying the progress of other participants who had the opportunity for intensive mentored performance.

As an appropriate method of teaching skill-type subject matter as shown in Husnu's study (2018), demonstration is effective in developing the English pronunciation skills as indicated in Moedjito's reappraisal study (2018). Also, demonstration can support student teacher preparation for the future career teaching performance as concluded in Negru's, Juica's, \& Stojanovic's study (2016).

Thus, demonstration was incorporated in flipped classroom. Such integration increased the in-class time for intensive practice and allowed the participants to master the target skills or practical techniques by having 


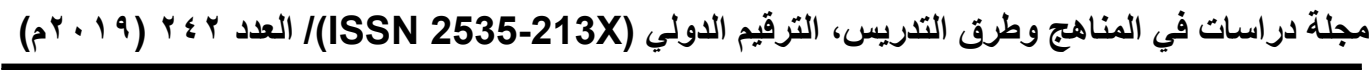

Audio-visual explanatory modeling (before the class) followed by mentored performance and assessment (during the class). Consequently, flipped demonstration led the participants to increase gains on the ILOs of English pronunciation learning and teaching modules as shown in Webb's \& Doman's study (2016).

\section{Qualitative data discussion of open interviews}

When asked about their motivation, participants pointed out that they were highly enthusiastic to get engaged actively in what they learnt through flipped classroom rather than traditional lecturing. This was crystal clear during the six-week treatment as both researchers noticed two good points. First, full class attendance showed the participants' great interest. They were satisfied as they were strictly punctual. Second, participants' hard work reflected their reliability and responsibility for what they learnt as they were highly committed with the content acquisition and application. Such motivation higly propelled KG prospective teachers' perseverance to resolve their fossilized mispronunciation.

Also, participants confirmed that they were no more afraid of learning or teaching English. This was revealed by the findings of the studies that were conducted by Alsowat (2016), Zainuddin (2017), Chen Hsieh, Wu, \& Marek (2017), Lin \& Hwang (2018) as well as Sağlam \& Arslan (2018). The findings pointed out that flipped classroom had a higher positive effect on university learners' achievement, engagement, satisfaction and attitudes towards English courses than the traditional instruction.

Considering the use of time, participants preferred the repetition that was possible outside-class whenever needed to grasp the content according 


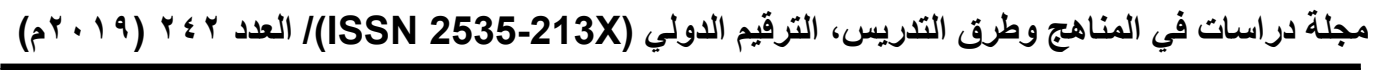

to their own self-pacing as explained by Mehring (2016). This saved time for in-class intensive practice and mentored performance. Such wellorganized time management was the reason for their ability to improve their pronunciation teaching performance and encounter the difficulties of their fossilized mispronunciation.

From the perspective of reaching the required materials, few participants could hardly get them online. They had it on flash drive or DVD. They either had face-to-face discussion, peer assessment and peer tutoring or used their mobile technologies for discussions and exchange their recorded speech production or teaching performance for peer assessment and peer tutoring. However, all participants asserted that they might have had problems if videos were not carefully selected and if they were not supported by PPT/Flash presentations, discussions, peer assessment and peer tutoring.

Regarding flipped demonstration's effect on learning, they claimed that watching videos and studying the related materials before the class made them familiar with the topic of teaching which, in turn, allowed for their interactive intensive practice in the class. This is consistent with the findings of Farrah's study (2018) that aimed to investigate the university English majors' attitudes towards the flipped classroom.

In addition, participants explained that flipped demonstration had positive impact and supported their mastery learning for three main reasons: Self-pacing, Peer Assessment and Peer Tutoring. Such mastery learning guaranteed participants' serious and remedial treatment of their fossilized mispronunciation. 
First, participants were allowed to accomplish the ILOs through the self-paced nature of the provided instructional multimedia-based materials (going backwards and forwards) which supported more flexibility that made them more autonomous. Second, participants exchanged their videorecorded speech production and teaching performance outside the class for peer assessment and online (via various technologies such mobile and tablet) or face-to-face discussions before the class. This helped them get prepared well for practice in the class. Third, peer tutoring was done after the class and supported by discussions to provide assistance to unsuccessful participants who failed in reaching the mastery level after the formative assessment during the class. Unsuccessful participants were allowed to replay the in-class personal video-recordings of the successful participants and review them with the clever peer tutors. This encouraged them to figure out their weaknesses to master the production of the target pronunciation features and the use of pronunciation teaching techniques.

Finally, they were asked about how useful the flipped demonstration program for their future. All participants asserted their bad need of learning English pronunciation as well as improving their performance of teaching English pronunciation to KG kids. They indicated that the program could facilitate the opportunity for them to get a well-paid job as $\mathrm{KG}$ language teachers in private schools since it helped them promote their essential professional skills to be included later in their resume after graduation. Based on the participants' responses in the open interviews, the proposed flipped demonstration program was found out to be beneficial to them. Thus, the fifth question was answered. 


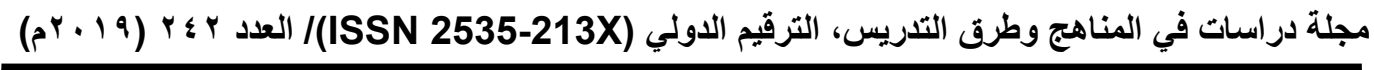

\section{Conclusion}

Based on the results of the present research, flipped demonstration as a proposed integrated pedagogical approach had a high positive effect on developing the KG prospective teachers' basic English pronunciation skills as well as on improving their English pronunciation teaching performance. Thus, it can be concluded that flipped demonstration may be helpful in teacher preparation skill-type programs at faculties of education since their future career requires technical practices \& skill training in different areas.

\section{Recommendations and Suggestions}

Recommendations

The following are the recommendations of the current research:

1. In higher education, flipped classroom changes the university tutor's role from a sage on the stage to a guide and increases class attendance.

2. When teaching EFL like pronunciation, flipped classroom works as a scaffolding since students can learn the language by watching professional videos of skillful native speaker teachers.

3. As a method of teaching, flipped classroom can be integrated with other teaching methods, strategies or techniques to make use of its benefits as it helps them get prepared well before the class and this, in turn, expands their involvement in learning, increases interactive practice and enhance tutor-mentored performance during the class.

4. For course developers, using flipped classroom allows for providing the students with a well-organized and professional multimedia-based content gist which encourages self-pacing and self-learning. 


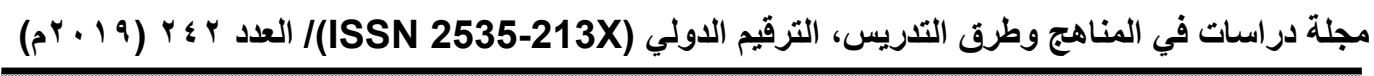

Suggestions

Here are some suggestions for possible further research:

1. The Effect of Flipped Demonstration on students' English pronunciation skills at the Faculty of Tourism and Hotels.

2. The Impact of Flipped Demonstration on University English majors' English teaching skills at the Faculty of Education.

3. Flipped Demonstration Program for Developing EFL Public Speaking Skills among Students at the Faculty of Commerce.

4. Flipped Demonstration module for developing English majors' writing skills at the Faculty of Education or Arts \& Humanities. 


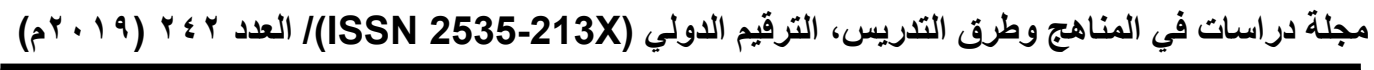

\section{References}

Abeysekera, L. \& Dawson, P. (2015). Motivation and cognitive load in the flipped classroom: definition, rationale and a call for research. Higher Education Research \& Development, 34(1), 1-14.

Acedo, M. (2018, January 8). 10 Pros and Cons of a Flipped Classroom [Blog post]. Retrieved from https://www.teachthought.com learning/10-pros-cons-flipped-classroom/

Adult Migrant English Program Research Centre. (2002). Fact Sheet Setting Goals for Teaching Pronunciation. Retrieved from http://www.ameprc.mq.edu.au/docs/fact_sheets/02Pronunciation .pdf

Ahmad, S.Z. (2016). The Flipped Classroom Model to Develop Egyptian EFL Students' Listening Comprehension. English Language Teaching, 9(9), 166-178. Retrieved from ERIC database. (EJ1110998)

Akyol, T. (2013). A Study on Identifying Pronunciation Learning Strategies of Turkish EFL Learners. Social and Behavioural Sciences, $\quad 70(2), \quad$ 1456-1462. $\quad$ https://doi:10.1016/j.sbspro .2013 .01 .211

Alsowat, H. (2016). An EFL Flipped Classroom Teaching Model: Effects on English Language Higher-order Thinking Skills, Student Engagement and Satisfaction. Journal of Education and Practice, 7(9), 108-121. Retrieved from ERIC database. (EJ1095734)

Arnold-Garza, S. (2014). The Flipped Classroom Teaching Model and its Use for Information Literacy Instruction. Communications in Information Literacy, 8(1), 7-22. Retrieved from ERIC database. (EJ1089137) 


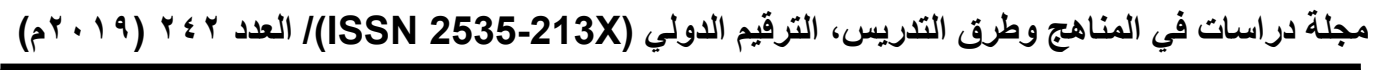

Avery, P., \& Ehrlich, S. (2013). Teaching American English Pronunciation - Oxford Handbooks for Language Teachers. Oxford University Press

Filiz, S. \& Benzet, A. (2018). A Content Analysis of the Studies on the Use of Flipped Classrooms in Foreign Language Education. World Journal of Education, 8(4), 72-86. https://doi.org/10.5430/ wje . $\mathrm{v} 8 \mathrm{n} 4 \mathrm{p} 72$

Bear, K. (2018). How to Teach Pronunciation Level Appropriate Suggestions on Teaching English Pronunciation Skills. Retrieved from https://www.thoughtco.com/how-to-teach-pronunciation $\underline{-1210483}$

Bergmann, J. \& Sama, A. (2014). Flipped Classroom. Association of Christian Schools International, 17(3), 24-27. Retrieved from https://www.acsi.org/

Bodorík, M. (2017). Teaching English pronunciation by non-native teachers as seen by Slovak teachers. Journal of Language and Cultural Education, 5(3), 157-174. https://doi.org/10.1515/j olace $\underline{-2017-0034}$

Boyraz, S. \& Ocak, G. (2017). Implementation of flipped education into Turkish EFL teaching context. Journal of Language and Linguistic Studies, 13(2), 426-439. Retrieved from ERIC database. (EJ1159156)

Celce-Murcia, M., Brinton, D.M., \& Goodwin, J.M. (2006). Teaching Pronunciation: A Reference for Teachers of English to Speakers of other languages. US: Cambridge University Press

Chen Hsieh, J.S., Wu, W.C.V., \& Marek, M.W. (2017). Using the Flipped Classroom to Enhance EFL Learning. Computer Assisted Language Learning, 30(1-2), 1-21. Retrieved from ERIC database. (EJ1134034) 
Cunningham, U. (2015). Teaching English Pronunciation Online to Swedish Primary-School Teachers. In E. Waniek-Klimczak, M. Pawlak (Eds.), Teaching and Researching the Pronunciation of English. Second Language Learning and Teaching (pp. 63-76). New York: Springer Cham. https://doi.org/10.1007/978-3-319 $\underline{-11092-9 \_4}$

Dunn, O. (n.d.). How young children learn English as another language. Retrieved August 23, 2018, from https://learnenglishkids .britishcouncil.org/helping-your-child/how-young-children-learn -english-another-language

Farrah, M. (2018). English Students'Attitudes TowardsUsing Flipped Classrooms in Language Learning at Hebron University. Research in English Language Pedagogy, 6(2), 275-294. Retrieved from http://relp.khuisf.ac.ir/

Farooq, U. (2013, November 18). Demonstration Method of Teaching Meaning, Advantages \& Disadvantages [Blog post]. Retrieved from http://www.studylecturenotes.com/curriculum-instructions /demonstration-method-of-teaching-meaning-advantages -disadvant ages

Francisco, D. (2017). Demonstration Method. Retrieved August 22, 2018, from https://www.slideshare.net/DayneFrancisco/demonstration -method-72052014?from action=save

Gil, I.R., De Larios, J.R., \& Balibrea, Y.C. (2017). The Effect of Repeated Reading on the Pronunciation of Young EFL Learners. Porta Linguarum, 27, 7-19. Retrieved from https://www.ugr.es

Gilakjani, A. P. (2012). A Study of Factors Affecting EFL Learners' English Pronunciation Learning and the Strategies for Instruction. International Journal of Humanities and Social Science, 2(3), 119128. 


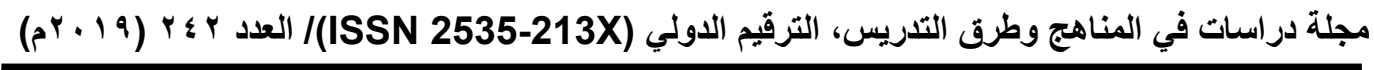

Gilakjani, A. P. (2016). English Pronunciation Instruction: A Literature Review. International Journal of Research in English Education, 1(1), 1-6. Retrieved from www.ijreeonline.com

Higher Education Academy. (2017). Flipped Learning. Retrieved July 17, 2018, from https://www.heacademy.ac.uk/knowledge-hub/flipped -learning-0

Husnu, M. (2018). Demonstration Technique to Improve Vocabulary and Grammar Element in Teaching Speaking at EFL Learners. English Language Teaching, 11(2), 26-30. Retrieved from ERIC database. (EJ1166126)

Katz, W.F. (2013). Phonetic for Dummies. Canada: John Wiley \& Sons, Inc.

Kenworthy, J. (1988). Teaching English Pronunciation. Hong Kong: Longman Group UK Limited.

Koroglu, Z.C. \& Cakir, A. (2017). Implementation of flipped instruction in language classrooms: An alternative way to develop speaking skills of pre-service English language teachers. International Journal of Education and Development using Information and Communication Technology, 13(2), 42-55. Retrieved from ERIC database. (EJ1153321)

Lane, L. \& Brown, H.D. (2010). Tips for Teaching Pronunciation: A Practical Approach. Pearson Education

Laroy, C. (2008). Resource Books for Teachers: Pronunciation. UK: Oxford University Press

Lin, C.J. \& Hwang, G.J. (2018). A Learning Analytics Approach to Investigating Factors Affecting EFL Students' Oral Performance in a Flipped Classroom. Educational Technology \& Society, 21(2), 205-219. Retrieved from ERIC database. (EJ1175299) 


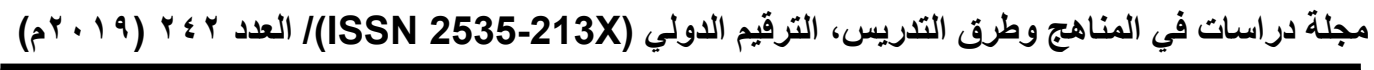

Mangade, L. (2010, May 12). FOI-Various Methods of InstructionDemonstration-Performance Method [Video file]. Retrieved from https://www.youtube.com/watch?v=ZphingQYZwo

Martin, K.E. (2013). Goals and Priorities for English Pronunciation Instruction: Report Presented to the Faculty of the Graduate School of The University of Texas at Austin. Retrieved from https://repositories.lib.utexas.edu/bitstream/handle/2152/22724 /MARTIN-MASTERSREPORT-2013.pdf?sequence $=1$

Mehring, J. (2016). Present Research on the Flipped Classroom and Potential Tools for the EFL Classroom. Computers in the Schools, 33(1), 1-10. Retrieved from ERIC database. (EJ1091997)

Melissa. (2012, August 27). The Montessori Method for Teaching the Letter Sounds [Blog post]. Retrieved from http://vibrantwander ings.com/2012/08/the-montessori-method-for-teaching-the-lettersounds.html

Moedjito. (2018). Improving EFL Learners' Pronunciation of English through Quiz-Demonstration-Practice-Revision (QDPR). English Language Teaching, 11(1), 10-20. Retrieved from ERIC database. (EJ1162485)

National Reading Panel. (n.d.). Phonics Instruction. Retrieved August 22, 2018, from http://www.readingrockets.org/article/phonics -instruction

Negru, M., Juica, B., \& Stojanovic, A. (2016). DEMONSTRATION AND OBSERVATION OF TEACHING. Journal Plus Education, XVI(oct.), 165-175

Nunan, D. (2003). Practical English Language Teaching ( $1^{\text {st }}$ ed.). Singapore: McGraw-Hill Companies. 
Obari, H. \& Lambacher, S. (2015). Successful EFL teaching using mobile technologies in a flipped classroom. In F. Helm, L. Bradley, M. Guarda, \& S. Thouësny (Eds), Critical CALL - Proceedings of the 2015 EUROCALL Conference (pp. 433-438). Italy: Researchpublishing.net. http://dx.doi.org/10.14705/ rpnet.2015.000371

Odisho, E.Y. (2014). Pronunciation is in the Brain, not in the Mouth: A Cognitive Approach to Teaching it. USA: Gorgias Press LLC.

Oxford University Press ELT. (2012, October 25). English Language Teaching Global Blog: Pronunciation for Young Learners [Blog post]. Retrieved from https://oupeltglobalblog.com/2012/10 /25/pronunciation-for-young-learners/

Pappas, C. (2012, December 7). What Is A Flipped Classroom? [Blog post]. Retrieved from https://elearningindustry.com/flipped -classroom-2012-infographic

ReadingByPhonics.com. (n.d.). What is Synthetic Phonics? The Most Effective Method to Teach Reading. Retrieved September 12, 2018, from https://www.readingbyphonics.com/about-phonics /synthetic-phonics.html

Reid, E. (2016). TEACHING ENGLISH PRONUNCIATION TO DIFFERENT AGE GROUPS. Retrieved from https://www .researchgate.net/publication/312495294_TEACHING_ENGLISH _PRONUNCIATION_TO_DIFFERENT_AGE_GROUPS.

Roach, P. (2012). English Phonetics and Phonology: A practical course ( $5^{\text {th }}$ ed.). UK: Cambridge University Press.

Rosenberg, T. (2013, October 23). In 'Flipped' Classrooms, a Method for Mastery [Blog post]. Retrieved from https://opinionator.blogs .nytimes.com/2013/10/23/in-flipped-classrooms-a-method-for -mastery 


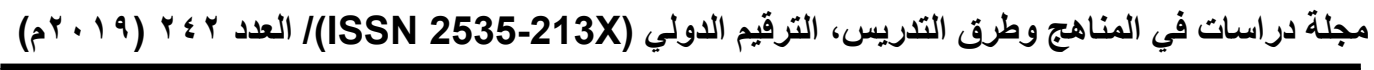

Sağlam, D. \& Arslan, A. (2018). The Effect of Flipped Classroom on the Academic Achievement and Attitude of Higher Education Students. World Journal of Education, 8(4), 170-176. https://doi .org/10.5 430/wje.v8n4p170

Sasi, K. (2012). Demonstration Method. Retrieved September 21, 2018, from https://www.slideshare.net/ksasi1/demonstration-method

Tersoo, A. (2018, January 6). Definition, advantages, and disadvantages of demonstration method of teaching [Blog post]. Retrieved from https://www.legit.ng/1142120-definition-advantages-disadvantages -demonstration-method-teaching.html

Texas Faculty Innovation Center. (2013, July 23). What is a flipped class? [Video file]. Retrieved from https://vimeo.com/70893101

Tomčíková, N. (2006). Developing Pronunciation with Young Learners. University of Pardubice: Faculty of Arts and Philosophy.

Webb, M. \& Doman, E. (2016). Does the Flipped Classroom Lead to Increased Gains on Learning Outcomes in ESL/EFL Contexts? The CATESOL Journal, 28(1), 39-67. Retrieved from ERIC database. (EJ1111606)

Wolff, L.C. \& Chan, J. (2016). Defining Flipped Classrooms. In SpringerBriefs in Law (Eds.), Flipped Classrooms for Legal Education (pp. 9-13). Singapore: Springer. https://doi.org/10 $.1007 / 978-981-10-0479-7 \_2$

Wu, W.C.V., Hsieh, J.S.C., \& Yang, J.C. (2017). Creating an Online Learning Community in a Flipped Classroom to Enhance EFL Learners' Oral Proficiency. Educational Technology \& Society, 20(2), 142-157. Retrieved from ERIC database. (EJ1137524)

Zainuddin, Z. (2017). First-Year College Students' Experiences in the EFL Flipped Classroom: A Case Study in Indonesia. International Journal of Instruction, 10(1), 133-150. Retrieved from ERIC database. (EJ1125139) 